\title{
Assessment of the mycorrhizal community in the rhizosphere of maize (Zea mays L.) genotypes contrasting for phosphorus efficiency in the acid savannas of Brazil using denaturing gradient gel electrophoresis (DGGE)
}

\author{
Christiane A. Oliveira ${ }^{a, *}$, Nadja M.H. Sá ${ }^{a}$, Eliane A. Gomes ${ }^{b}$, Ivanildo E. Marriel ${ }^{b}$, \\ Maria R. Scotti ${ }^{a}$, Claudia T. Guimarães ${ }^{b}$, Robert E. Schaffert ${ }^{b}$, Vera M.C. Alves ${ }^{b}$ \\ ${ }^{a}$ Federal University of Minas Gerais, Botany Department, PO box 486, 31270-901 Belo Horizonte, MG, Brazil \\ ${ }^{\mathrm{b}}$ Embrapa Maize and Sorghum, PO box 151, 35701-970 Sete Lagoas, MG, Brazil
}

\section{A R T I C L E I N F O}

\section{Article history:}

Received 4 April 2008

Received in revised form

6 November 2008

Accepted 14 November 2008

Keywords:

Acid low P soils

Arbuscular mycorrhizal fungi (AMF)

Corn

$P$ acquisition

PCR-DGGE

\begin{abstract}
A B S T R A C T
Community structure of indigenous arbuscular mycorrhizal fungi (AMF) in the rhizosphere of tropical maize genotypes contrasting for phosphorus efficiency was evaluated using denaturing gradient gel electrophoresis (DGGE). Fragments of AMF ribosomal DNA (rDNA) were amplified using nested PCR with fungal universal primers and ITS (internal transcribed spacer) specific primers for Acaulosporaceae, Glomaceae and Gigasporaceae. ITS-Acaulosporaceae and Glomaceae-specific primers and DGGE were efficient in differentiating the composition of mycorrhizal communities. Maize genotypes had a greater influence on the rhizosphere mycorrhizal community than the level of P in the soil. DGGE profiles of maize roots revealed bands that were present only in P efficient genotypes (L3 and HT3060), suggesting that some mycorrhizal groups were stimulated by $P$ efficient maize genotypes. Acaulospora longula, A. rugosa, A. scrobiculata, A. morrowiae and Glomus caledonium were found only in the rhizosphere of $\mathrm{P}$ efficient maize genotypes cultivated in low P soils. A greater number of mycorrhizal DGGE bands were found in soil samples from no-till maize than conventional tillage. Effective mycorrhizal colonization of crops may influence the maize yield under Brazilian savanna acid soils by modulating the capacity of different cultivars to tolerate $\mathrm{P}$ deficiency.
\end{abstract}

(C) 2008 Elsevier B.V. All rights reserved.

\section{Introduction}

Low phosphorus (P) availability limits plant growth in many acid soils of the tropics such as the Oxisol soils of the Brazilian acid savannas (Cerrado), which are characterized by low $\mathrm{pH}$, low $\mathrm{P}$, and high $\mathrm{P}$ fixation capacity (Novais and Smyth, 1999; Hinsinger, 2001). Arbuscular mycorrhizal fungi (AMF) have an important function in soil nutrient acquisition and mobilization, principally phosphorus. The role of
AMF for nutrient acquisition is due to extending the root system by increasing the surface area for nutrient uptake and enhancing the ability of the plants to scavenge for scarce and immobile nutrients, particularly $\mathrm{P}$ (van der Heijden et al., 1998; Smith et al., 2003; Koide and Mosse, 2004; Gosling et al., 2006). The external mycelium mass can be as much as $3 \%$ of root mass and approximately $10-100 \mathrm{~m}$ of mycorrhizal mycelium can be found for each centimeter of root length (Cardoso and Kuyper, 2006). As a symbiotic

\footnotetext{
* Corresponding author at: Embrapa Milho e Sorgo, CP 151, 35701-970 Sete Lagoas, MG, Brazil. Tel.: +55 3137712774 ; fax: +55 3130271279.

E-mail address: paiva.christiane@yahoo.com.br (C.A. Oliveira).
} 
system, the fungi receive carbon sources from the host plant and provide nutrients to the plants (Grigera et al., 2007). AMF also improve the soil aggregate stability, as their extraradical hyphae can bind to soil particles mechanically and chemically through the exudation of glomalin (van der Heijden et al., 1998; Wright et al., 2005).

AMF root colonization in terms of contribution to nutrient acquisition differs markedly among fungal species, isolates, and host plant genotypes (Abbott and Robson, 1991; Marschner, 1995, 1998; Koide, 2000; Siqueira et al., 2002; Wright et al., 2005). Several reports have described positive effects of mycorrhizal association under low $P$ soil conditions in cereals, such as improvement in maize plant development and yield (Clark and Zeto, 1996). However, little information is available regarding the interaction of maize genotypes contrasting for $\mathrm{P}$ acquisition efficiency with AMF present in the rhizosphere of tropical maize.

According to Gosling et al. (2006) arbuscular mycorrhiza can be used in agriculture to increase crop yields while minimizing the requirements on chemical fertilizers. In spite of numerous studies claiming substantial yield increases, mycorrhizal technology is still far from being routinely applied in agricultural practices. The main reasons for this are problems in identifying and tracking fungal species in the field, the poor understanding of the basic biology of AMF and the inability to grow these obligatory biotrophic fungi in pure cultures and in trap cultures. Selection of appropriate AMF, production of inocula in quality and quantity, and the ecology of mycorrhiza inoculation are critical issues for the application of AMF technology in agriculture production (Simon et al., 1992; Gianinazzi et al., 2002; Barea et al., 2005a,b).

Cloning, sequencing and real-time PCR of products amplified with AMF-specific primers have contributed to the characterization of culture-independent AMF communities (Simon et al., 1992; Helgason et al., 1998; Redecker et al., 2000; Jansa et al., 2008; Liang et al., 2008). Molecular fingerprinting techniques such as denaturing gradient gel electrophoresis (DGGE) of ribosomal DNA (rDNA) fragments amplified from total community DNA have been widely used to evaluate the composition of bacterial and fungal communities (Muyzer and Smalla, 1998). The combination of DGGE with sequencing of amplified DNA fragments can be applied to analyze phylogenetic relationships of the community members. Few studies (Kowalchuk et al., 2002; Öpik et al., 2003; de Souza et al., 2004; Ma et al., 2005; Liang et al., 2008) have used this approach to study mycorrhizal fungi communities in the soil and rhizosphere.

The objective of this study was to evaluate the indigenous mycorrhizal community structure in the rhizosphere of maize genotypes contrasting for $\mathrm{P}$ acquisition efficiency and the effects of the maize cultivars on the fungal community structure in the acid savanna soils with high and low P. A set of PCR primers which amplify ribosomal DNA from five genera in the Glomeromycota (Redecker, 2000) was used to study a wide portion of AMF colonization. Additional evaluations of AMF colonization in maize roots and spore number in rhizosphere were made by stereomicroscopic visualization.

\section{Materials and methods}

\subsection{Field experimental design and sampling}

The field experiment was performed in an Oxisol soil (Brazilian savanna biome-Cerrado), during the summer (December through March), at Embrapa Maize and Sorghum located in Sete Lagoas, Minas Gerais, Brazil, at latitude $19^{\circ} 28^{\prime} \mathrm{S}$ and longitude $44^{\circ} 15^{\prime} \mathrm{W}$, at an altitude of $732 \mathrm{~m}$. The local climate is the $\mathrm{Aw}$, according to the Köppen classification, with a mean temperature $22^{\circ} \mathrm{C}$, mean annual rainfall $1300 \mathrm{~mm}$, and a mean relative humidity of $70 \%$. The experiment was a $2 \times 8$ factorial, soil P levels and genotypes respectively using a randomized complete block design with three replications. The maize genotypes consisted of three $P$ efficient hybrids (HT3060, HS228xL3, HS20x723), two P inefficient hybrids (HS2841x5046, HS26x1113), two efficient inbred lines (L228, L3) and one inefficient inbred line (L22), classified as differing in phosphorus acquisition efficiency according to Parentoni and Souza Júnior (2008). Each experimental plot consisted of 2 rows $5 \mathrm{~m}$ long with $0.8 \mathrm{~m}$ between rows and $0.2 \mathrm{~m}$ between plants, which were planted in two conventionally managed systems: high phosphorus (high P), with $29 \mathrm{mg} \mathrm{kg}^{-1}$, determined using a Mehlich I extraction (Embrapa, 1997) and a low phosphorus (low P), with $3 \mathrm{mg} \mathrm{kg}^{-1}$ (Mehlich I). The soil was a clay texture red Oxisol with $\mathrm{pH}$ of 5.2 (soil/water ratio, 1:2.5 [w/v]), organic matter (3\%); $\mathrm{Al}(0.25)$, Ca (2.29), $\mathrm{Mg}(0.36) \mathrm{cmol}_{\mathrm{C}} \mathrm{kg}^{-1}$ (dry mass) of soil in a $1 \mathrm{~N} \mathrm{KCl} \mathrm{extraction} \mathrm{and} 62 \mathrm{mg} \mathrm{kg}^{-1}$ of $\mathrm{K}$, in a Mehlich I extraction. The original available $\mathrm{P}$ status in this soil was $3 \mathrm{mg} \mathrm{kg}^{-1}$ (representing approximately only $30 \%$ of the critical level of $P$ for maize causing severe $P$ stress in these tropical soils) and the high P managed system was correct to $29 \mathrm{mg} \mathrm{kg}^{-1}$ obtained after fertilization with superphosphate $\left(45 \% \mathrm{P}_{2} \mathrm{O}_{5}\right)$ broadcast and incorporated into the soil at $20 \mathrm{~cm}$ depth. The available $\mathrm{P}$ was determined before the samples were taken.

The samples were composed of the roots and soil adhering to the roots of five random plants within each plot, collected from a depth between 0 and $20 \mathrm{~cm}$ for each of three replicates, 60 days after sowing during the flowering stage. The roots were shaken vigorously to separate the rhizosphere soil from the roots. The bulk soil samples were taken between rows from low and high $\mathrm{P}$ conditions of the treatments described above. Additional soil samples were taken from a no-till maize field and native savanna vegetation as controls. The samples used for DNA extraction were stored at $4{ }^{\circ} \mathrm{C}$ during transport to the laboratory, where the samples were sieved to remove plants debris, transferred to sealed glass flasks, and stored in nature at $-20^{\circ} \mathrm{C}$ for 4 months until DNA extraction.

\subsection{Spore isolation and spore counts}

Arbuscular mycorrhizal fungi spores were extracted from rhizosphere soil samples of each genotype in triplicate from $100 \mathrm{~g}$ of rhizosphere soil by sucrose centrifugation and flotation and collected on 250, 125, 63 and $32 \mathrm{~mm}$ mesh wet sieves according to the methodology described by Clapp et al. (1996). 


\subsection{AMF staining and root examination}

Individual roots of each genotype were picked randomly from the root samples collected, and cut into $1 \mathrm{~cm}$ length pieces. One hundred root fragments for each sample were analyzed for the presence of AMF mycelia after root staining. Before the staining, roots were clarified in $5 \%(\mathrm{w} / \mathrm{v}) \mathrm{KOH}$ for $1 \mathrm{~h}$, followed by acidification with $1 \% \mathrm{HCl}(\mathrm{v} / \mathrm{v})$ overnight. The roots were stained with $0.05 \%$ Trypan Blue (w/v) for $20 \mathrm{~min}$ in lactoglycerol acid and were visualized under stereomicroscope. Colonization percentage was assessed using the grid line intersect method (Giovannetti and Mosse, 1980).

\subsection{Spore and total community DNA extraction}

DNA was extracted from $500 \mathrm{mg}$ of soil of a pooled sample composed of the three replicates using the protocol described in the soil DNA extraction and purification kit (FastDNA SPIN kit for soil, Bio 101 Inc., La Jolla, CA, USA). DNA of AMF isolated spores was used as a control in all denaturing gradient gel electrophoresis (DGGE). Isolates from the Cerrado biome of Acaulospora morrowiae (grassland isolate), A. serobienta (coffee isolate), Gigaspora margarita (maize isolate), Glomus clarum (grassland isolate), G. etunicatum (grassland isolate) and Scutellospora sp. (maize isolate) were provided by Prof. J.O. Siqueira, Federal University of Lavras, Minas Gerais, Brazil. DNA from spores were extracted directly from trap cultures of vermiculite containing pure culture of the spores using the FastDNA SPIN kit for soil according to the modified protocol described by Chellius and Triplett (1999).

\subsection{Total AMF-specific PCR conditions}

PCR amplification of AMF 18 S ribosomal genes fragments was performed using a nested PCR with fungal universal primers, NS1 and NS4 (White et al., 1990) for the first step and AMFspecific primer, VANS1 and NS21 (Simon et al., 1992) for the second step. The VANS1 primer was attached with CG clamp (Muyzer and Smalla, 1998). Amplification reactions were performed in a final volume of $50 \mu \mathrm{l}$ using $50 \mu \mathrm{M}$ of each dNTP, $2.5 \mathrm{mM} \mathrm{MgCl}_{2}, 20 \mathrm{mM}$ Tris-HCl (pH 8.4), $50 \mathrm{mM} \mathrm{KCl}, 1 \%$ (v/v) formamide, $0.2 \mu \mathrm{M}$ of each primer, $20 \mathrm{ng}$ of DNA and 1 unit of Taq DNA polymerase (Invitrogen, Carlsbad, CA, USA). PCR conditions were: $95^{\circ} \mathrm{C}$ for $2 \mathrm{~min}$, followed by 40 cycles of first step and 25 cycles of second step (nested) at $94^{\circ} \mathrm{C}$ for $20 \mathrm{~s}$, $55^{\circ} \mathrm{C}$ for $35 \mathrm{~s}, 72^{\circ} \mathrm{C}$ for $1 \mathrm{~min}$, and a final extension step at $72{ }^{\circ} \mathrm{C}$ for $5 \mathrm{~min}$. Amplified fragments were separated on a $1.5 \%(\mathrm{w} / \mathrm{v})$ agarose gel, stained with ethidium bromide $\left(1 \mu \mathrm{g} \mathrm{ml}^{-1}\right)$, and visualized under UV Eagle Eye II (Stratagene, La Jolla, CA, USA).

\subsection{Specific PCR conditions for Acaulosporaceae, Glomaceae, Gigasporaceae families}

The first nested PCR step to obtain Acaulosporaceae and Glomaceae-specific amplification products from soil was performed combining the primers NS5 and ITS4 (White et al., 1990). These amplification products were used as a template for a second PCR step using the primers ACAU1660, GLOM1310 (Redecker et al., 2000) with GC clamp specific to Acaulosporaceae and Glomaceae, respectively, in combination with the primer ITS2 (White et al., 1990). Gigasporaceae-specific fragments were obtained after a first step amplification using the primers pair ITS1 and ITS4 and a second step with ITS1 and GIGA5.8R (Redecker et al., 2000) attached with GC clamp. PCR conditions were the same as described above.

\subsection{Analysis of PCR products by DGGE}

DGGE was performed with the DCode Universal Mutation Detection System (Bio-Rad Laboratories, Hercules, CA, USA). A volume of $20 \mu \mathrm{l}$ of the PCR reaction was applied directly onto polyacrylamide gel in $1 \times$ TAE buffer $(20 \mathrm{mM}$ Tris-acetate $[\mathrm{pH}$ 7.4], $10 \mathrm{mM}$ sodium acetate, $0.5 \mathrm{mM}$ disodium EDTA). Denaturing gradients varied for each primer combination, which were 35-60\% for VANS1/NS21 and ACAU1660/ITS2, 25-50\% for GLOM1310/ITS2, and 40-70\% for ITS1/GIGA5.8R. These gradients were formed with $6 \%(\mathrm{w} / \mathrm{v})$ acrylamide stock solutions containing 0 and 100\% denaturant condition [7 M urea and $40 \%$ (v/v) deionized formamide]. Fragments were separated under electrophoresis at $75 \mathrm{~V}$ for $16 \mathrm{~h}$ in $0.5 \times \mathrm{TAE}$ buffer at a constant temperature of $60^{\circ} \mathrm{C}$. Gels were silver stained according to Creste et al. (2001) and the images were digitally captured by a Nikon digital camera.

\subsection{Sequencing purified fragments from DGGE gels and sequence alignment}

Amplified DNA fragments were recovered using a second DGGE gel using the same conditions but stained with ethidium bromide. The most prominent bands were excised and transferred to a microcentrifuge tube containing $50 \mu \mathrm{l}$ of ultrapure water, incubated at room temperature for two hours and frozen overnight. Some bands were purified and new gels were prepared to test the existence of double bands and contamination. Subsequently, the gel fragment was centrifuged at $11,000 \times g$ for $60 \mathrm{~s}$, the supernatant was transferred to a new tube, and $5 \mu$ l of eluted DNA was used as a template for an additional PCR reaction with the same conditions. PCR products were separated on a $1.5 \%(\mathrm{w} / \mathrm{v})$ agarose gel, stained with ethidium bromide $\left(1 \mu \mathrm{g} \mathrm{ml}^{-1}\right)$, and visualized under UV Eagle Eye II (Stratagene, La Jolla, CA) transillumination. PCR products were purified using QIAquick Gel Extraction kit (Qiagen, Hilden, Germany) and sequenced using the kit "Big Dye Terminator v3.1 Cycle Sequencing” (Applied Biosystems, Foster City, CA, USA) in an ABI PRISM 3100 Genetic Analyzer (Applied Biosystems). Nucleotide sequence data were compared with those from the GenBank (http://www.ncbi.nlm.nih.gov/) using the BlastN program (Altschul et al., 1997).

\subsection{Data analysis}

Percentage values of root colonization and spore counts were transformed using arcsin before factorial analysis of variance (ANOVA) among maize cultivars and phosphorus levels. Tukey's test at 5\% significance was applied for comparison of means when appropriate.

DGGE banding patterns were assessed by cluster analysis with a percent disagreement coefficient, and the differences among the profiles of AMF communities were depicted as a 
dendrogram constructed by the unweighted pair group with mathematical average method (UPGMA) using the software Statistica version 6.0 .

\section{Results}

\subsection{Mycorrhizal colonization and AMF spores}

The occurrence of indigenous mycorrhizal infection in maize varied among genotypes and $\mathrm{P}$ levels in the soil (Fig. 1A and B). Although, the percentage of mycorrhizal colonization was not clearly different between $P$ efficient and inefficient maize hybrids (Fig. 1A), the $\mathrm{P}$ efficient inbred lines (Fig. 1B) showed higher mycorrhizal colonization in comparison with the inefficient line for both levels of $\mathrm{P}$. Colonization of the $\mathrm{P}$ inefficient line was significantly lower than the efficient lines at both levels of P in the soil (Fig. 1B). L3 under P stress showed an increase in AMF-like infection of about $20 \%$ when compared with high $P$ soil.

The recovery of AMF spores from different rhizosphere soils of maize cultivars also varied between genotypes and $\mathrm{P}$ levels (Fig. 1C and D). For the maize hybrids, the number of spores was greater in the low P soils, except for the P inefficient hybrid HS26x1113 (Fig. 1C). However, for the P efficient maize inbred line, L3, the total number of spores was superior in the high P soils compared to the low P soils (Fig. 1D).

\subsection{DGGE analysis of AM fungal rhizosphere colonization}

The primers used in this study, VANS1/NS21, ACAU1660/ITS2, GLOM1310/ITS2 and GIGA5.8R/ITS1 amplified PCR products with the expected sizes of 590, 445, 645 and 440 base pairs, respectively. Subsequent DGGE analysis were conducted with pooled samples (no variation was observed between replicates) of PCR products composted from three replicates of the field samples taken from one lane to DGGE. The DGGE patterns for VANS1/NS21 fragments from the maize rhizosphere amplified a wide range of non-AMF taxon, indicating that the VANS1 primer was not able to distinguish the AMF populations between the maize genotypes.

Thus, DGGE analysis was conducted with fungal specific rDNA primers covering three families of Glomeromycota; the Acaulosporaceae, Glomaceae and Gigasporaceae. All different specific AMF primers revealed detectable fragments in the DGGE, from which bands were excised from the gels, reamplified and sequenced (Table 1).

\subsection{Acaulosporaceae and Glomaceae-specific DGGE and sequence analysis of amplified bands}

PCR-DGGE of the Acaulosporaceae/Glomaceae-specific primers for the ITS rDNA gene differentiated all rhizosphere samples (Figs. 2 and 3). Almost all the samples yielded multiple bands, indicating the presence of ribotype variability within the rhizospheres examined.

The Acaulosporaceae-specific DGGE banding patterns of the maize hybrids rhizosphere revealed one major cluster, which grouped most of the $\mathrm{P}$ efficient hybrids at a genetic distance of 0.26 , except for the P efficient HT3060 under low P (Fig. 2A). Additionally, the two $\mathrm{P}$ inefficient hybrids were clustered in different groups depending on the level of $P$ in the soil, both of them at a genetic distance of 0.21 .

A greater number of bands of the Acaulosporaceae DGGE were observed in the maize lines, but with no clear discriminatory factor of the cluster analysis (Fig. 2B). However,
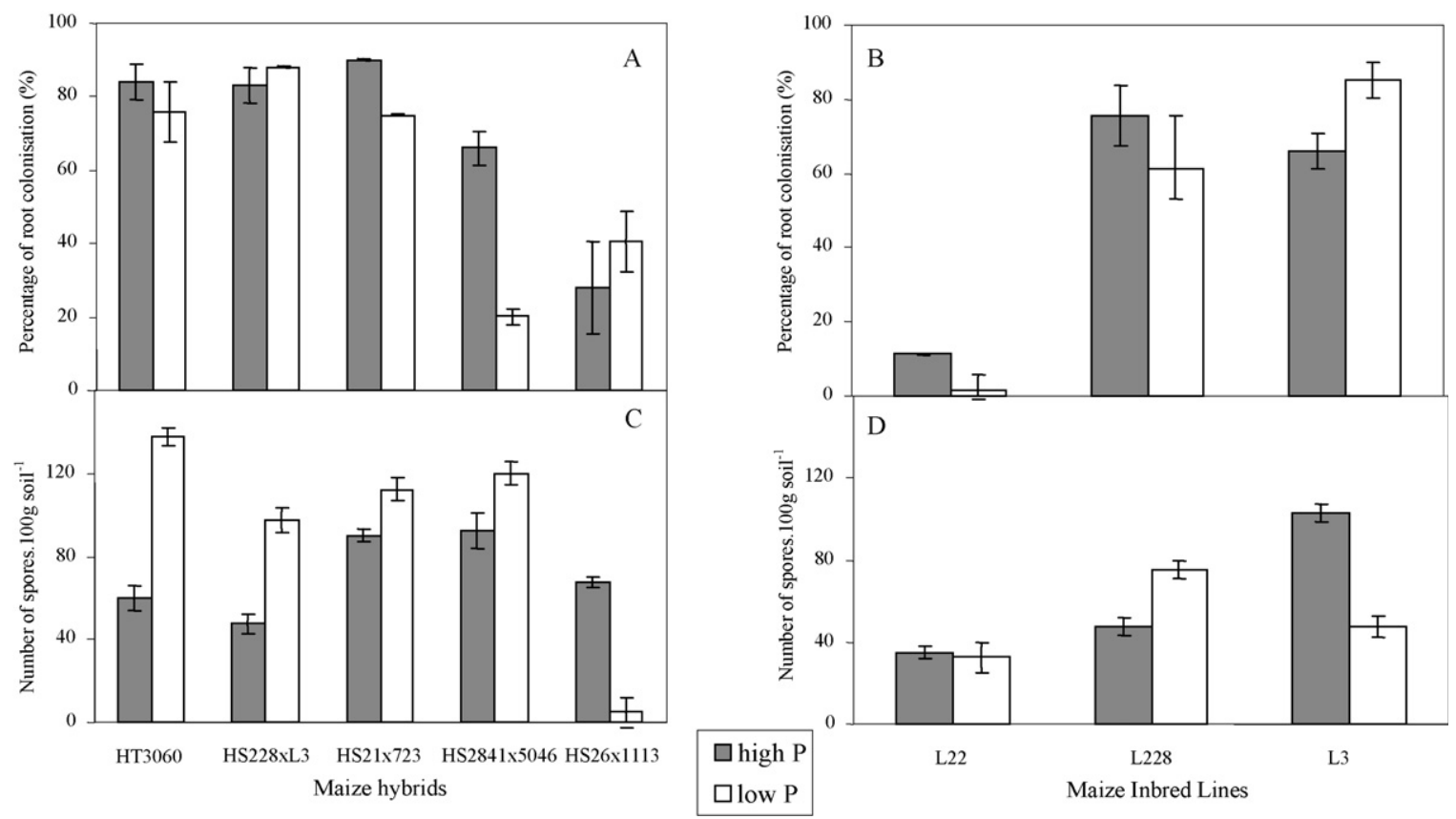

Fig. 1 - Colonization of maize roots growing under low P soil fertilization $\left(3 \mathrm{mg} \mathrm{kg}^{-1}\right)$ and high $P\left(29 \mathrm{mg} \mathrm{kg}{ }^{-1}\right)$ by indigenous mycorrhizal fungi. The hybrids in graphs A and C were: HT3060, HS228xL3, HS20x723 (P efficient), and HS2841x5046, H26x1113 (P inefficient). The inbred lines in graphs B and D were: L228, L3 (P efficient) and L22 (P inefficient). Each data columns represent a mean of three replicates; error bars represent the standard error at the $5 \%$ level. 
Table 1 - The closest species of the mycorrhiza present in maize rhizosphere that were recovered from DGGE bands.

DGGE band ${ }^{\mathrm{a}}$

Closest species

Microorganisms $^{\mathrm{b}}$ (\% similarity)

Phylogenetic affiliation

GenBank accession number ${ }^{b}$

Acaulosporaceae-specific DGGE

$\begin{array}{ll}1 & \text { Acaulospora scrobicula (88\%) } \\ 2 & \text { A. morrowiae (88\%) } \\ 3 & \text { Glomus intraradices (94\%) } \\ 4 & \text { G. intraradices (97\%) } \\ 5 & \text { Glomus sp. 0191 (98\%) } \\ 6 & \text { A. rugosa (93\%) } \\ 7 & \text { Ajellomyces capsulatus }{ }^{c}(100 \%) \\ 8 & \text { Soil clone } \\ 9 & \text { Archaeospora sp. (93\%) } \\ 10 & \text { A. longula (89\%) } \\ 11 & \text { Archaeospora sp. (94\%) } \\ 12 & \text { G. intraradices (100\%) } \\ 13 & \text { Archaeospora sp. (94\%) } \\ 14 & \text { G. intraradices (96\%) } \\ 15 & \text { Glomus sp. (98\%) } \\ 16 & \text { A. morrowiae (88\%) }\end{array}$

Glomaceae-specific DGGE

$\begin{array}{ll}17 & \text { Glomus caledonium (98\%) } \\ 18 & \text { Glomus mosseae (91\%) } \\ 19 & \text { Glomus sp. clone 0171 (94\%) } \\ 20 & \text { Glomus sp. clone W3347 (98\%) } \\ 21 & \text { Glomus sp. clone 0171 (96\%) } \\ 22 & \text { Glomus sp. clone W3347 (96\%) } \\ 23 & \text { Glomus sp. clone 0171 (95\%) } \\ 24 & \text { G. coremioides (95\%) } \\ 25 & \text { G. coremioides (96\%) } \\ 26 & \text { G. coremioides (98\%) } \\ 27 & \text { Glomus sp. 5014b25 (90\%) } \\ 28 & \text { G. manihotis (93\%) } \\ 29 & \text { Glomus sp. clone 0171 (96\%) } \\ 30 & \text { Glomus sp. clone W3347 (92\%) } \\ 31 & \text { Glomus sp. 5014b24 (93\%) } \\ 32 & \text { G. mosseae (98\%) } \\ 33 & \text { Glomus sp. 5014b25 (93\%) } \\ 34 & \text { Glomus sp. clone 0171 (95\%) } \\ \text { Gigasporaceae-specific DGGE } \\ 35 & \text { Scutellospora cerradensis (85\%) } \\ 36,37 & \text { Soil clone } \\ 38 & \text { Gigaspora margarita (100\%) }\end{array}$

$\begin{array}{ll}\text { Acaulosporaceae } & \text { AJ306442 } \\ \text { Acaulosporaceae } & \text { AJ242500 } \\ \text { Glomaceae } & \text { AF185692 } \\ \text { Glomaceae } & \text { AF185692 } \\ \text { Glomaceae } & \text { AY174693 } \\ \text { Acaulosporaceae } & \text { Z14005 } \\ \text { Ajellomycetaceae } & \text { AF322387 } \\ \text { - } & \end{array}$

Archaeosporaceae AF452636

Acaulosporaceae AJ306439

Archaeosporaceae AF452636

Glomaceae AF185692

Archaeosporaceae AF452636

Glomaceae AF185692

Glomaceae AF452626

Acaulosporaceae AJ242500

Glomaceae $\quad$ Y17635

Glomaceae X96828

Glomaceae AY174691.1

Glomaceae AJ301857

Glomaceae AY174691.1

Glomaceae AJ301857

Glomaceae AY174691.1

Glomaceae AJ249715

Glomaceae AJ249715

Glomaceae AJ249715

Glomaceae AF480158.1

Glomaceae $\quad$ Y17648

Glomaceae AY174691.1

Glomaceae AJ301857

Glomaceae AF480157.1

Glomaceae X96828

Glomaceae $\quad$ AF480157.1

Glomaceae AY174691.1

$\begin{array}{ll}\text { Gigasporaceae } \quad \text { AB048690.1 } & \end{array}$

- $\begin{array}{ll}\text { Gigasporaceae } & \text { AY442360.1 }\end{array}$

${ }^{a}$ DGGE bands designation are as labeled in Figs. 2-4.

b Most related isolate from GenBank by BLAST results.

c Species belong to Ascomycota order.

the bulk soil (low P) sample and the L22 (low P) rhizosphere sample were clustered at a genetic distance of 0.06 and supported by a $90 \%$ bootstrap, indicating that this line, under low $\mathrm{P}$, probably did not influence the AMF community. The most distinct DGGE banding pattern was observed in the Acaulosporaceae community of native Cerrado, suggesting that maize cultivation affected the mycorrhizal Acaulosporaceae community. In addition, the samples from the no-tillage system were clustered at 0.11 genetic distance with a support of $87 \%$ bootstrap, distinctly different from the conventional rhizosphere samples.

Sequence analysis did not confirm the family specificity of some bands amplified with Acaulosporaceae-specific primers once species of Ascomycota phylum and the Glomaceae family were identified, as Ajellomyces capsulatus and Glomus sp., respectively (Table 1). Acaulospora species were found in the rhizosphere of the P efficient maize genotypes L3 (low P) and HT3060 (low P), corresponding to A. scrobiculata (1), A. morrowiae (2), A. rugosa (6), and A. longula (10) species (Fig. 2, Table 1). Band 8 was found in the rhizosphere of most of the hybrids but its sequence did not align with any sequence deposited in the GenBank, indicating that this sequence belongs to an unknown species. Different bands amplified in some unique DGGE lanes were identified as belonging to the same species, like bands 3 and 4 that corresponded to Glomus intraradices (Table 1, Fig. 2).

The dendrogram based on the banding patterns of the Glomaceae-specific DGGE generated a cluster at a genetic distance of 0.18 that included the rhizosphere of the P efficient and inefficient maize hybrids cultivated in high $\mathrm{P}$ soils 


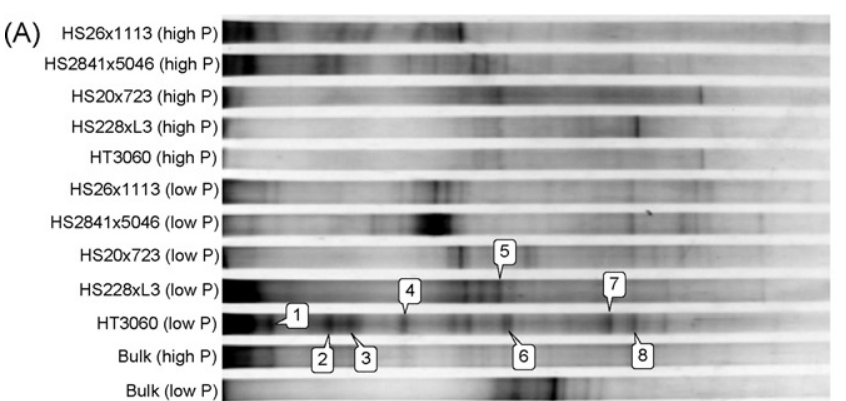

(B)

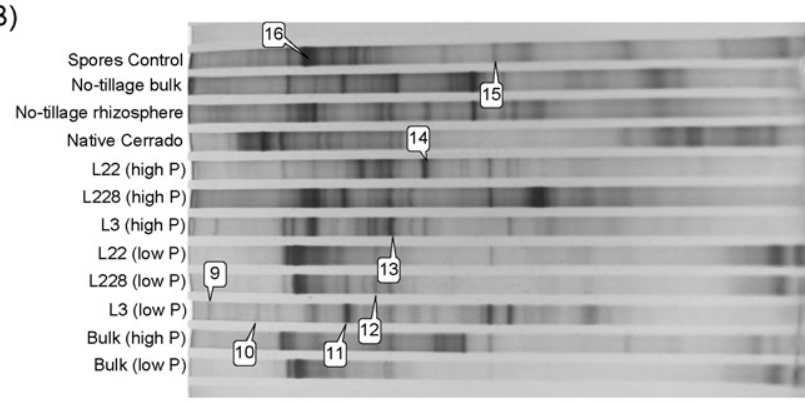

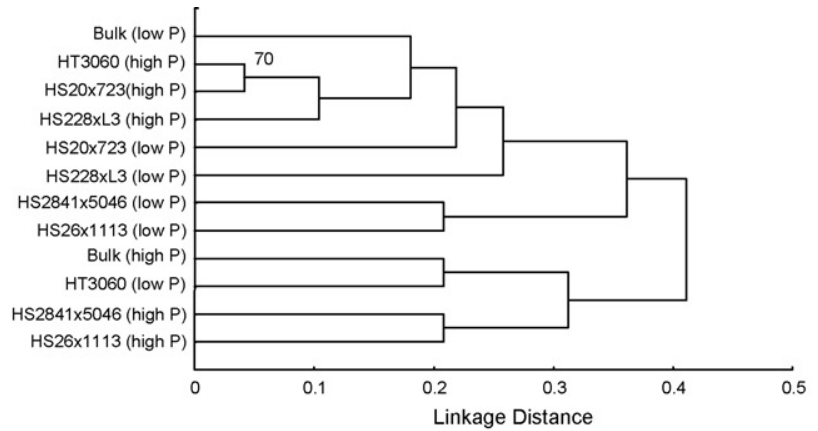

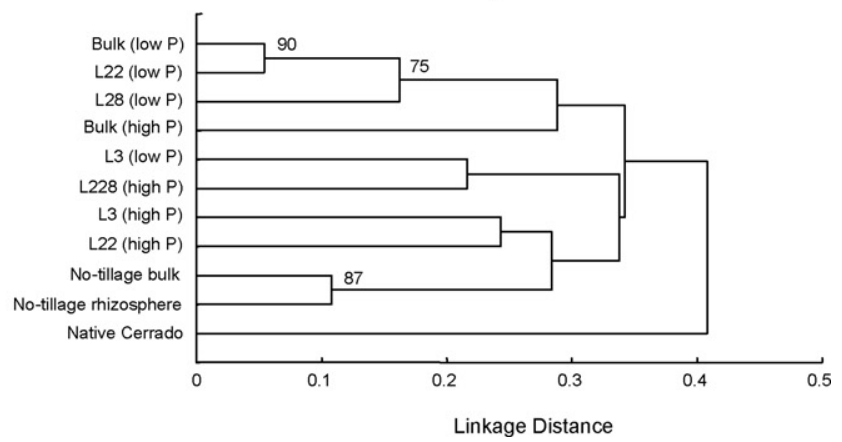

Fig. 2 - Acaulosporaceae-specific PCR-DGGE banding patterns of rhizosphere soil and the dendrogram from maize hybrids (A) and inbred lines (B). The dendrogram was obtained by the unweighted pair group method with mathematical averages (UPGMA). The hybrids in graphs were: HT3060, HS228xL3, HS20x723 (P efficient), and HS2841x5046, H26x1113 (P inefficient). The inbred lines in graphs were: L228, L3 (P efficient) and L22 (P inefficient). Lane spores control, composed by PCR products of Acaulospora morrowiae and A. serobienta spores. The numbers indicate different bands among the samples identified in Table 1. Bootstrap analyses were performed with 10,000 repetitions.
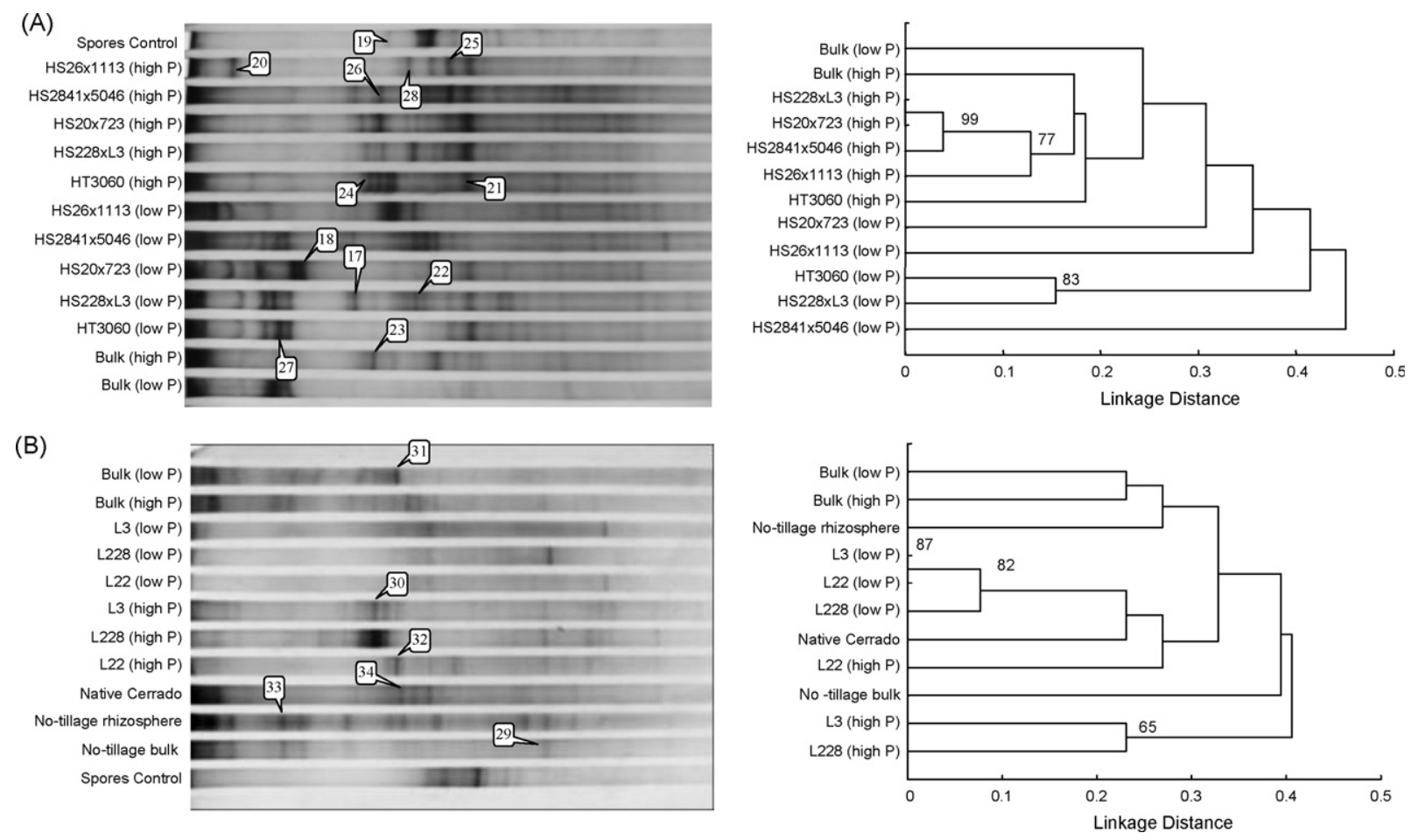

Fig. 3 - Glomaceae-specific PCR-DGGE banding patterns of rhizosphere soil and the dendrogram from maize hybrids (A) and inbred lines (B). The dendrogram was obtained by the unweighted pair group method with mathematical averages (UPGMA). The hybrids in graphs were: HT3060, HS228xL3, HS20x723 (P efficient), and HS2841x5046, H26x1113 (P inefficient). Lane spores control, composed by PCR products of Glomus clarum and G. etunicatum spores. The inbred lines in graphs were: L228, L3 (P efficient) and L22 ( $P$ inefficient). The numbers indicate different bands among the samples identified in Table 1. Bootstrap analyses were performed with 10,000 repetitions. 
(Fig. 3A). However, the low P soils were not consistently grouped, except for the two P efficient hybrids (HT3060 and HS228xL3) that formed clusters based on the bootstrap value of $83 \%$. The greatest Glomus spp. DGGE bands in the rhizosphere of maize hybrids was found in low P soils. The AMF populations of two different $P$ efficient maize hybrids under low P (HT3060 and HS228xL3) were grouped at a genetic distance of 0.16 (bootstrap 83\%) (Fig. 3B) in contrast with the $\mathrm{P}$ inefficient hybrids.

The $P$ availability in the soil seems to be a putative discriminating factor of clustering the Glomaceae populations of the maize lines rhizosphere, which were grouped under low $\mathrm{P}$ at a genetic distance of 0.08 and supported by a bootstrap value of $82 \%$ (Fig. 3B). The P efficient maize lines rhizosphere, L228 and L3 in the high P soil were also grouped at a genetic distance of 0.23 ( $65 \%$ bootstrap). Additionally, the rhizosphere profiles obtained under high $\mathrm{P}$ soil showed exclusive bands that could not be visualized in low P soils (see bands 30, 32, Fig. 3B).

Sequence analysis (Table 1) confirmed the identity of all fragments from Glomaceae-DGGE bands as belonging to the genus Glomus, with some bands being exclusively present in the rhizosphere of the P efficient maize genotypes (Fig. 3), such as Glomus caledonium in HS228xL3 (low P). However, similarity of some sequences is not sufficiently high (91\%) to confirm the species, as shown in Table 1 to Glomus mosseae.

\subsection{Gigasporaceae-specific DGGE and sequence analysis of excised DGGE bands}

The specific Gigasporaceae PCR-DGGE yielded bands that provided a low level of discrimination within the different maize samples. The fingerprints generated showed a lower number of bands than the Acaulosporaceae and Glomaceae families. A prevalent monomorphic band was identified as $G$. margarita (band 38, Table 1) in the rhizosphere of all the maize hybrids (data not shown) and lines (Fig. 4). However, an exclusive band (band 35, Fig. 4) presented in the L228 under

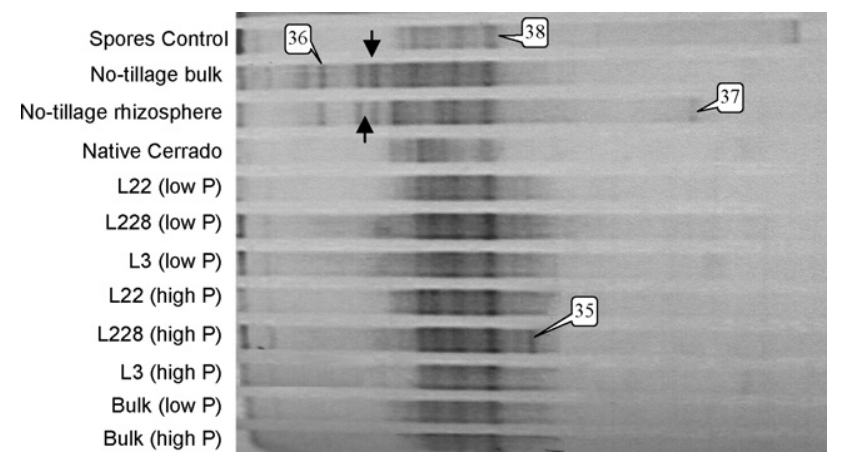

Fig. 4 - Gigasporaceae-specific PCR-DGGE banding patterns of rhizosphere soil of maize inbred lines. The inbred lines were: L228, L3 (P efficient) and L22 (P inefficient). Lane spores control, composed by PCR products of Gigaspora margarita and Scutellospora sp. spores. The numbers indicate different bands among samples identified in Table 1. Arrows indicate bands present in the no-tillage system and absent in the conventional system and in the native Cerrado. high $\mathrm{P}$ was identified as Scutellospora cerradensis. The Gigasporaceae community was not influenced by the P availability in the soil or by the maize genotypes. However, the no-tillage system generated bands that were absent in the conventional crop management and in the native Cerrado (see arrows and band 36, Fig. 4).

\section{Discussion}

The knowledge of the structure and composition of the mycorrhizal community in the rhizosphere is important to evaluate the environmental effects, such as phosphorus stress, on plant species. Preliminary fingerprints of the rhizosphere mycorrhizal community were generated by DGGE using universal primer pairs designed by Simon et al. (1992) to assess the diversity of maize rhizosphere indigenous AMF populations cultivated under low and high $\mathrm{P}$ soil. The $18 \mathrm{~S}$ rDNA region amplified by the VANS1/NS21 primer pair provided a low level of discrimination among the samples and the majority of the sequenced bands were not related to the Glomeromycota phylum. Studies have shown that the VANS1 annealing site is not well conserved within the Glomeromycota (Clapp et al., 1999) and that several newly characterized ancestral lineages of the Glomeromycota do not have this site at all (Redecker et al., 2000). Similar results were observed by Ma et al. (2005) and Öpik et al. (2003) using the AM1 and NS31 primers described by Helgason et al. (1998) and Simon et al. (1992).

Thus, the PCR-DGGE method using specific primers to ITS rDNA fragments designed by Redecker et al. (2000) was better suited to amplify species of Acaulosporaceae, and Glomaceae in the rhizosphere of maize. These data, together with the visual analyses of AMF colonization showed that both maize genotypes and the level of $\mathrm{P}$ in the soil influenced the total population density (spores number and AMF root colonization) as well as the AMF species (DGGE bands).

Few differences were found in spore density among $P$ efficient and inefficient genotypes evaluated. In contrast, the Acaulosporaceae and Glomaceae PCR-DGGE profiles showed exclusive bands, found only in the P efficient genotypes under low P. In general, these results showed that AMF root colonization and DGGE profiles in a majority of the efficient maize genotypes available in this study were different from the inefficient maize genotypes AMF community, suggesting that the level of P efficiency of maize genotypes may influence the community of AMF in the rhizosphere. The difference in the occurrence of mycorrhiza species may depend upon root exudations and/or signaling of the maize genotype under $\mathrm{P}$ stress. According to Lynch and Whipps (1990), Marschner (1998), Barea et al. (2005b), root exudates are crucial determinants of rhizosphere microorganism diversity. Plants grown in soils with $\mathrm{P}$ deficiency can exudate functional substances, such as organic acids, jasmonic acid, phosphatases and phenolic compounds which can stimulate colonization and growth of the mycorrhiza (Gianinazzi-Pearson et al., 1989; Siqueira et al., 1991; Marschner, 1998; Lambais, 2000; Hinsinger, 2001; Koide and Mosse, 2004) and influence host-AMF specificity. 
The variability in mycorrhizal responsiveness among different maize cultivars has also been observed by Kaeppler et al. (2000) and Wright et al. (2005). The ability of plants to grow under $\mathrm{P}$ stress and the efficiency of mycorrhiza colonization are both strongly influenced by the host genotype (Marschner, 1995; Smith et al., 2003; Wright et al., 2005). Several authors have demonstrated that the maize genotypes used in this study have significant differences in P efficiency (Alves et al., 1999; Parentoni and Souza Júnior, 2008). Some authors have documented increases in maize productivity with AMF colonization (Clark and Zeto, 1996; Kaeppler et al., 2000; Wright et al., 2005) and others have shown the effect of the crop genotype and soil type on the bacteria and fungi community profiles (Gomes et al., 2001, 2003; Mota et al., 2002). This is the first report with these maize genotypes contrasting for P efficiency demonstrating AMF diversity and community structure in the acid savannas of Brazil. The understanding of the mechanisms that increase $P$ acquisition can be very useful in delineating strategies in maize breeding programs to select genotypes which favor early support of large populations of AMF (Alves et al., 1999; Picard et al., 2008), and continued research to characterize AMF community composition including genes controlling host signaling is warranted.

The specific Acaulosporaceae PCR-DGGE was efficient in differentiating AMF populations in the maize rhizosphere samples evaluated in this study. However, sequence analysis did not confirm the identity of some bands amplified with AMF-specific primer (ACAU1660) being identified as species of other groups of fungi and others families of Glomeromycota. Further primer refinement (Redecker et al., 2000) should increase the reliability of PCR-based strategies targeting specific AMF families or genera such as the primer (ACAU1660) was not efficient for the DGGE method used in this study.

Some AMF-like sequences did not match with any sequence deposited in the GenBank, indicating that these sequences may belong to new AMF, still not identified. A double-band pattern of Glomus was observed in this study, similarly to that reported by Kowalchuk et al. (2002) and de Souza et al. (2004) for Glomus and Gigaspora genera, respectively. Some authors have suggested that operon heterogeneity may be responsible for these double bands (Sanders et al., 1995; Clapp et al., 1999; Kowalchuk et al., 2002; Ma et al., 2005). The variability of some rRNA loci in an AMF community may lead to complex DGGE banding patterns from a single spore (Ma et al., 2005). This heterogeneity in rRNA markers within a species or a single individual has been described for a wide range of organisms (Kuhn et al., 2001; Dahllof et al., 2000; Araujo da Silva et al., 2003), including AMF fungi (Clapp et al., 1999; Kowalchuk et al., 2002; Sanders, 2002; de Souza et al., 2004; Liang et al., 2008). The origin of this diversity is still undetermined but the heterokaryotic nuclei of AMF could explain the presence of unusual polymorphisms within ribosomal DNA revealed by DGGE profiles (Kuhn et al., 2001). However, this issue was not addressed in our study because the DNA was extracted from soil samples containing multiple spores.

Mycorrhiza populations of the three AMF families described above was also affected by the cropping system. Clear differences were found between conventional tillage and notillage management systems, forming separated groups by the DGGE profiles of Acaulosporaceae and Glomaceae. Additionally, specific bands (for example 33, 36) were obtained from the no- till system for all AMF families evaluated. Greater mycorrhizal populations in a maize no-till system were also found by Jansa et al. (2003). Kabir (2005) evaluated AMF hyphal density and nutrient content in maize cultivated under no-till and conventional tillage for 11 years and found that AMF hyphae length and densities in the maize rhizosphere was highest in the no-tillage treatment. These changes in communities of AMF colonizing maize roots might be due to (1) differences in hyphae maintenance disruption caused by tillage, (2) changes in organic matter and nutrient content of the soil, (3) changes in microbial activity, and/or (4) changes in weed populations in response to the soil tillage system. Different AMF species differ in their symbiotic efficiency (Smith et al., 2003), and thus any induced changes in AMF community structure could lead to changes in crop nutrient uptake and/or productivity.

DGGE fingerprints based upon rDNA fragments amplified by nested PCR from community DNA were effective in studying mycorrhiza community structures in the maize rhizosphere. This analysis was supported by DNA sequencing, except for the Acaulosporaceae primers used and by visualization of mycorrhizal colonization and spore counts. These results clearly show that the maize genotypes and the Plevel in the soil can influence the mycorrhiza populations, indicating that some mycorrhizal groups are enhanced by efficient maize genotypes cultivated under contrasting $\mathrm{P}$ availability in the soil.

Understanding the community structure of the native AM fungi in crop root systems is a prerequisite for effective management in sustainable agricultural systems, especially in acidic soils with low $\mathrm{P}$, typically encountered in the Brazilian Cerrado. The productivity of maize may depend upon the symbiotic effectiveness of the colonizing mycorrhiza and the maize cultivar. The use and understanding of the genetic control of the exudation of mycorrhiza signaling products by the host plant and the use of these metabolites should be helpful in managing useful native AMF populations.

\section{Acknowledgements}

This work was supported by Embrapa Maize and Sorghum and McKnight Foundation. C.A. Oliveira acknowledges Brazilian Council for Scientific and Technological Development (CNPq) for supporting her Ph.D. studies. We thank Professor Dr. Lucy Seldin (University of Rio de Janeiro, Brazil) for their technical support and comments for discussion on the manuscript and Professor Dr. José Oswaldo Siqueira (University of Lavras, Brazil), for kindly providing AM fungal spore cultures.

\section{R E F E R E N C E S}

Abbott, L.K., Robson, A.D., 1991. Factors influencing the occurrence of vesicular-arbuscular mycorrhizas. Agric. Ecosyst. Environ. 35, 121-150.

Altschul, S.F., Madden, T.L., Schaeffer, A.A., 1997. Gapped blast and psi-blast: a new generation of protein database search programs. Nucleic Acids Res. 25, 3389-3402.

Alves, V.M.C., Magalhães, J.V., Novais, R.F., Bahia Filho, A.F.C., Oliveira, C.A., França, C.C.M., 1999. Acúmulo de nitrogênio e de fósforo em plantas de milho afetado pelo suprimento 
parcial de fósforo às raízes. Rev. Bras. Ciênc. Solo 23, 299-305.

Araujo da Silva, K.R., Salles, J.F., Seldin, L., Van Elsas, J.D., 2003. Application of a novel Paenibacillus-specific PCR-DGGE method and sequence analysis to assess the diversity of Paenibacillus spp. in the maize rhizosphere. J. Microbiol. Methods 54, 213-231.

Barea, J.M., Azcón, R., Azcón-Aguilar, C., 2005a. Interactions between mycorrhizal fungi and bacteria to improve plant nutrient cycling and soil structure. In: Buscot, F., Varma, S. (Eds.), Microorganisms in Soils: Roles in Genesis and Functions. Springer-Verlag, Heidelberg, Germany, pp. 195-212.

Barea, J.M., Werner, D., Azcón-Aguilar, C., Azcón, R., $2005 b$. Interactions of arbuscular mycorrhiza and nitrogen fixing symbioses in sustainable agriculture. In: Werner, D., Newton, W.E. (Eds.), Agriculture, Forestry, Ecology and the Environment. Kluwer Academic Publishers, The Netherlands, pp. 199-222.

Cardoso, I.M., Kuyper, T.W., 2006. Mycorrhizas and tropical soil fertility. Agric. Ecosyst. Environ. 116, 72-84.

Chellius, K.M., Triplett, E.W., 1999. Rapid detection of arbuscular mycorrhiza in roots and soil of an intensively managed turfgrass system by PCR amplification of small subunit rDNA. Mycorrhiza 9, 61-64.

Clapp, J.P., Fitter, A.H., Merryweather, J.W., 1996. Arbuscular mycorrhizas. In: Hall, G.S. (Ed.), Methods for the Examination of Organism Diversity in Soils and Sediments. CAB International, New York, pp. 145-161.

Clapp, J.P., Fitter, A.H., Young, J.P.W., 1999. Ribosomal small sub-unit sequence variation within spores of an arbuscular mycorrhizal fungus, Scutellospora sp. Mol. Ecol. 8, 915-921.

Clark, R.B., Zeto, S.K., 1996. Growth and root colonization of mycorrhizal maize grown on acid and alkaline soil. Soil Biol. Biochem. 28, 1505-1511.

Creste, S., Tullman-Neto, A., Figueira, A., 2001. Detection of single sequence repeat polymorphisms in denaturing polyacrilamide sequencing gels by silver staining. Plant Mol. Biol. Rep. 19, 299-306.

Dahllof, I., Baillie, H., Kjelleberg, S., 2000. rpoB-based microbial community analysis avoids limitations inherent in $16 \mathrm{~S}$ rRNA gene intraspecies heterogeneity. Appl. Environ. Microbiol. 66, 3376-3380.

de Souza, F.A., Kowalchuk, G.A., Leeflang, P., van Veen, J.A., Smit, E., 2004. PCR-denaturing gradient gel electrophoresis profiling of inter- and intraspecies 18S rRNA gene sequence heterogeneity is an accurate and sensitive method to assess species diversity of arbuscular mycorrhizal fungi of the genus Gigaspora. Appl. Environ. Microbiol. 70, 1413-1424.

Embrapa, 1997. Manual de métodos de análise de solo, 2 ed. Centro Nacional de Pesquisa de Solos, Brasília, 212 pp.

Gianinazzi, S., Schüepp, H., Barea, J.M., Haselwandter, K. (Eds.), 2002. Mycorrhizal Technology in Agriculture: From Genes to Bioproducts. Birkhaüser Verlag, Basel, Switzerland, p. 296.

Gianinazzi-Pearson, V., Branzanti, B., Gianinazzi, S., 1989. In vitro enhancement of spore germination and early hyphal growth of a vesicular-arbuscular mycorrhizal fungus by host root exudates and plant flavonoids. Symbiosis 7 , 243-255.

Giovannetti, M., Mosse, B., 1980. An evaluation of techniques for measuring vesicular-arbuscular mycorrhizal infection in roots. New Phytol. 84, 489-500.

Gomes, N.C.M., Fagbola, O., Costa, R., Rumjanek, N.G., Buchner, A., Mendona-Hagler, L., Smalla, K., 2003. Dynamics of fungal communities in bulk and maize rhizosphere soil in the tropics. Appl. Environ. Microbiol. 69, 3758-3766.

Gomes, N.C.M., Heuer, H., Schönfeld, J., Costa, R., MendonaHagler, L., Smalla, K., 2001. Bacterial diversity of the rhizosphere of maize (Zea mays) grown in tropical soil studied by temperature gradient gel electrophoresis. Plant Soil 232, 167-180.

Gosling, P., Hodge, A., Goodlass, G., Bending, G.D., 2006. Arbuscular mycorrhizal fungi and organic farming. Agric. Ecosyst. Environ. 113, 17-35.

Grigera, M.S., Drijber, R.A., Wienhold, B.J., 2007. Abundance of arbuscular mycorrhizal fungi in soil coincides with the reproductive stages of maize. Soil Biol. Biochem. 39, 1401-1409.

Helgason, T., Daniell, T.J., Husband, R., Fitter, A.H., Young, J.P.W., 1998. Ploughing up the wood-wide web? Nature $384,431$.

Hinsinger, P., 2001. Bioavailability of soil inorganic $P$ in the rhizhosphere as affected by root-induced chemical changes: a review. Plant Soil 237, 173-195.

Jansa, J., Andrew Smith, F., Smith, S.E., 2008. Are there benefits of simultaneous root colonization by different arbuscular mycorrhizal fungi? New Phytol. 177, 779-789.

Jansa, J., Mozafar, A., Kuhn, G., Anken, T., Ruh, R., Sanders, I.R., Frossard, E., 2003. Soil tillage affects the community structure of mycorrhizal fungi in maize roots. Ecol. Appl. 13, 1164-1176.

Kabir, Z., 2005. Tillage or no-tillage: impact on mycorrhizae. Can. J. Plant Sci. 85, 23-29.

Kaeppler, S.M., Parke, J.L., Mueller, S.M., Senior, L., Stuber, C., Tracy, W.F., 2000. Variation among maize inbred lines and detection of quantitative trait loci for growth at low phosphorus and responsiveness to arbuscular mycorrhizal colonization. Crop Sci. 40, 358-364.

Koide, R.T., 2000. Functional complementarily in the arbuscular mycorrhizal symbiosis. New Phytol. 147, 233-235.

Koide, R.T., Mosse, B., 2004. A history of research on arbuscular mycorrhiza. Mycorrhiza 14, 145-163.

Kowalchuk, G.A., de Souza, F.A., van Veen, J.A., 2002. Community analysis of arbuscular mycorrhizal fungi associated with Ammophila arenaria in Dutch coastal sand dunes. Mol. Ecol. 11, 571-581.

Kuhn, G., Hijri, M., Sanders, I.R., 2001. Evidence for the evolution of multiple genomes in arbuscular mycorrhizal fungi. Nature 414, 745-748.

Lambais, M.R., 2000. Regulation of plant defense-related genes in arbuscular mycorrhizae. In: Podila, G.K., Douds, D.D. (Eds.), Current Advances in Mycorrhizae Research. American Phytopathological Society Press, St. Paul, Minneapolis, pp. 46-60.

Liang, Z., Drijber, R.A., Lee, D.J., Dwiekat, I.M., Harris, S.D., Wedin, D.A., 2008. A DGGE-cloning method to characterize arbuscular mycorrhizal community structure in soil. Soil Biol. Biochem. 40, 956-966.

Lynch, J.M., Whipps, J.M., 1990. Substrate flow in the rhizosphere. Plant Soil 129, 1-10.

Ma, W.K., Siciliano, S.D., Germida, J.J., 2005. A PCR-DGGE method for detecting arbuscular mycorrhizal fungi in cultivated soils. Soil Biol. Biochem. 37, 1589-1597.

Marschner, H., 1995. Mineral Nutrition of Higher Plants, 2 ed. Academic Press, London, $889 \mathrm{pp}$.

Marschner, H., 1998. Role of root growth, arbuscular mycorrhiza, and root exudates for the efficiency in nutrient acquisition. Field Crops Res. 56, 203-207.

Mota, F.F., Nóbrega, A., Marriel, I.E., Paiva, E., Seldin, L., 2002. Diversity of Paenibacillus polymyxa strains isolated from the rhizosphere of four maize genotypes planted in Cerrado soil. Appl. Soil Ecol. 20, 119-132.

Muyzer, G., Smalla, K., 1998. The need for DGGE and TGGE in microbial ecology. Antonie Van Leeuwenhoek 73, 127-141.

Novais, R.F., Smyth, T.J., 1999. Fósforo em solo e planta em condições tropicais. Universidade Federal de Viçosa, Viçosa, 399 pp. 
Öpik, M., Moora, M., Liira, J., Kõljalg, U., Zobel, M., Sen, R., 2003. Divergent arbuscular mycorrhizal fungal communities colonize roots of Pulsatilla spp. in boreal Scots pine forest and grassland soils. New Phytol. 160, 581-593.

Parentoni, S.N., Souza Júnior, C.L.de., 2008. Phosphorus acquisition and internal utilization efficiency in tropical maize genotypes. Pesqui. Agropecu. Bras. 43, 893-901.

Picard, C., Baruffa, E., Bosco, M., 2008. Enrichment and diversity of plant-probiotic microorganisms in the rhizosphere of hybrid maize during four growth cycles. Soil Biol. Biochem. 40, 106-115.

Redecker, D., 2000. Specific PCR primers to identify arbuscular mycorrhizal fungi within colonized roots. Mycorrhiza 10, 73-80.

Redecker, D., Morton, J.B., Bruns, T.D., 2000. Ancestral lineages of arbuscular mycorrhizal fungi (Glomales). Mol. Phylogenet. Evol. 14, 276-284.

Sanders, I.R., 2002. Ecology and evolution of multigenomic arbuscular mycorrhizal fungi. Am. Nat. 160, S128-S141.

Sanders, I.R., Alt, M., Groppe, K., Boller, T., Wiemken, A., 1995. Identification of ribosomal DNA polymorphisms among and within spores of the Glomales: application to studies on the genetic diversity of arbuscular mycorrhizal fungal communities. New Phytol. 130, 419-427.

Simon, L., Lalonde, M., Bruns, T.D., 1992. Specific amplification of $18 \mathrm{~S}$ fungal ribosomal genes from vesicular-arbuscular endomycorrhizal fungi colonizing roots. Appl. Environ. Microbiol. 54, 2908-2915.

Siqueira, J.O., Lambais, M.R., Sturmer, S.L., 2002. Fungos micorrízicos arbusculares: características, associação simbiótica e aplicação na agricultura. Biotecnolog. Cienc. Desenvolv. 5, 12-21.

Siqueira, J.O., Nair, M.G., Hammerschmidt, R., Safir, G.R., 1991. Significance of phenolic compounds in plant-soil microbial systems. CRC Crit. Rev. Plant Sci. 10, 63-121.

Smith, S.E., Smith, A.F., Jakobsen, I., 2003. Mycorrhizal fungi can dominate phosphate supply to plants irrespective of growth responses. Plant Physiol. 133, 16-20.

van der Heijden, M.G.A., Klironomos, J.N., Ursic, M., Moutoglis, P., Streitwolf-Engel, R., Boller, T., Wiemken, A., Sanders, I.R., 1998. Mycorrhizal fungal diversity determines plant biodiversity, ecosystem variability and productivity. Nature 396, 69-72.

White, T.J., Bruns, T., Lee, S., Taylor, J.W., 1990. Amplification and direct sequencing of fungal ribosomal RNA genes for phylogenetics. In: Innis, M.A., Gelfand, D.H., Sninsky, J.J., White, T.J. (Eds.), PCR Protocols: A Guide to Methods and Applications. Academic Press, San Diego, California, pp. 315-322.

Wright, D.P., Scholes, J.D., Read, D.J., Stephen, A., 2005. European and African maize cultivars differ in their physiological and molecular responses to mycorrhizal infection. New Phytol. 167, 881-896. 